\title{
PENINGKATAN NILAI PRODUK TELUR ASAP LURIK PADA BUMDES PRASAJA DESA BATURSARI KECAMATAN BATANGAN KABUPATEN PATI
}

\author{
Nurul Rizka Arumsari ${ }^{1{ }^{*}}$ | Dina Lusianti ${ }^{1^{*}} \mid$ Nova Laili Wisuda ${ }^{2 *}$ \\ Program Studi Manajemen ${ }^{1 ;}$ Program Studi Pertanian $^{2}$, Universitas Muria Kudus
}

\begin{abstract}
Abstrak
Telur Asap Lurik ialah hasil inovasi terbaru dari olahan telur asin. Telur ini menawarkan keunikan berupa motif telur yang bercorak lurik sebagai ciri khas Indonesia akan budaya batik. Pengasapan memberikan efek gurih dan lebih masir sekaligus menghilangkan bau amis yang biasa ditemui pada telur asin. Sebagai unit usaha yang berkembang di era revolusi industri 4.0 ini, telur asap lurik atau yang biasa dikenal dengan sebutan Telaslur memiliki tantangan besar dalam mengakses pasar yang kompetitif saat ini. Kegiatan pemasaran yang dilakukan oleh mitra melalui proses penjualan langsung kepada pelanggan dan mengikuti pameran. Model pemasaran dan penjualan produk yang dilakukan membuat akses pasar masih terbatas di wilayah Pati saja. Pemanfaatan teknologi dengan melalui pemasaran online dapat menjadi salah satu solusi untuk menambah profit bagi Bumdes Prasaja terutama kelompok Bina Farm. Metode yang digunakan untuk kegiatan pengabdian masyarakat adalah sosialisasi, pelatihan, implementasi program dan pendampingan pemeliharaan toko online. Mitra sangat antusias dan terbantu dengan adanya implementasi pemasaran online karena pengenalan toko dan kegiatan pemasaran dapat dilakukan dengan mudah dimanapun dan kapanpun melalui media toko online. Selain itu juga pengetahuan mitra atas pengetahuan tentang pemilihan packaging yang baik untuk menambah nilai produk telur asap lurik.
\end{abstract}

Kata Kunci: kewirausahaan, nilai produk, telur asap lurik

\section{Pendahuluan}

Makanan berpotensi untuk berperan dalam pasar global. Saat ini Indonesia tidak sepenuhnya swasembada pangan, dalam arti tidak seluruh wilayah dapat memenuhi sendiri kebutuhan pangannya yang beraneka ragam, sehingga pada saat tertentu memerlukan impor. Jika kemampuan produksi bahan pangan domestik tidak dapat mengikuti peningkatan kebutuhan, maka pada waktu yang akan datang Indonesia akan tergantung impor, yang berarti ketahanan pangan nasional akan semakin rentan karena akan semakin tergantung pada kebijakan ekonomi negara lain.

Berdasarkan perkiraan tersebut tantangan utama dalam pemantapan ketahanan pangan adalah optimalisasi pemanfaatan sumberdaya pangan domestik dan peningkatan kapasitas produksi pangan dalam jumlah, kualitas dan keragamannya. Konsumsi pangan hendaknya memperhatikan ketentuan zat gizi yang cukup berimbang, sesuai dengan kebutuhan bagi pembentukan manusia yang sehat, kuat, cerdas dan produktif. Dalam system konsumsi terdapat aspek penting yaitu diversifikasi. Diversifikasi pangan dimaksudkan untuk memperoleh keragaman zat gizi sekaligus melepas ketergantungan masyarakat atas satu jenis pangan tertentu. Ketergantungan yang tinggi dapat memicu ketidakstabilan jika pasokan terganggu dan sebaliknya jika masyarakat menyukai pangan alternatif maka ketidakstabilan akan dapat dijaga.

\footnotetext{
Penulis Korespondensi. Email: nurul.rizka@umk.ac.id; dina.lusianti@umk.ac.id; nova.laili@umk.ac.id
} 
Hasil pertanian dan budidaya pangan suatu daerah merupakan suatu aset ekonomi, budaya dan kesehatan masyarakat. Oleh karena itu sangat tepat apabila sasaran pembangunan bidang pangan di Indonesia diantaranya adalah; terwujudnya ketahanan pangan rumah tangga, terwujudnya diversifikasi pangan serta terjamin keamanan pangan. Keberadaan industri pengolahan makanan hasil pertanian di Indonesia yang paling besar adalah industri rumah tangga, kemudian industri kecil dan industri menengah dan besar.

Pengaruh internet dalam dunia bisnis membawa dampak sangat besar. Proses pemasaran melalui media internet dapat dilakukan setiap saat secara realtime tanpa terikat ruang dan waktu (Jinling, 2009). Kemudahan bertransaksi melalui media internet dan perubahan perilaku konsumen yang lebih menyukai bertransaksi secara online menjadi pemicu menjamurnya pemasaran online atau $e$-commerce. Pemanfaatan internet oleh pelaku usaha dapat menjadi salah satu strategi untuk menembus pasar yang lebih luas bahkan sangat mungkin menembus pasar global atau pasar ekspor. Adopsi pemasaran usaha secara digital atau online dapat menjadi salah satu faktor penting yang menentukan keberhasilan usaha (Prastuti, 2014).

Kinerja pemasaran melalui inovasi dan promosi produk dapat meningkatkan pertumbuhan UKM. Memperbaiki kinerja pemasaran UKM pada dasarnya adalah aliansi pemasaran dari sejumlah UKM terkoordinasi dalam kemitraan (Arumsari dan Marka, 2018). Desa Batursari adalah salah satu Desa di Kabupaten Pati dimana potensi wilayahnya bersumber dari pertanian dalam artian luas atau petambak ikan maupun garam. Dalam usaha taninya petani di desa Batursari tergantung dari Sawah tadah hujan dimana kebutuhan air tergantung dari turunnya hujan, ketersediaan air dapat diminimalkan dengan adanya Sumber air dibeberapa titik meskipun tidak mampu menunjang secara signifikan tetapi dengan keterbatasan inilah yang memotivasi Warga Desa Batursari untuk menjadikan Batursari sebagai Desa Wisata tani 2020 tidak hanya dalam budidayanya juga dalam pengolahan hasilnya.

Era globalisasi mensyaratkan terbukanya kesempatan untuk memasarkan produk maupun jasa masingmasing. Begitu pula dalam bidang pertanian. Hasil pertanian dan budidaya pangan suatu daerah merupakan suatu aset ekonomi, budaya dan kesehatan masyarakat. Permasalahan mendasar yang sering dihadapi adalah lemahnya skill dalam memasarkan produk olah hasil pertanian. Karena itu untuk memajukan usaha kecil yang memiliki daya saing yang kuat adalah dengan membangun strategi pemasaran yang baik dan tepat sasaran.

Mitra dalam kegiatan pengabdian kemitraan masyarakat ini adalah Bumdes Prasaja kelompok bina farm yang berlokasi di balai desa Batursari Kecamatan Batangan Kabupaten Pati. Diperoleh data dari hasil wawancara bahwa masyarakat di desa Batursari masih lemah dalam memasarkan hasil olah pertanian. Karena kurang pengetahuan mengenai strategi pemasaran secara menyeluruh serta rendahnya skill usaha yang dimiliki warga sekitar. Berdasarkan analisis situasi, penting kiranya kegiatan pengabdian kepada masyarakat sebagai salah satu upaya untuk menggerakkan, mengarahkan, memberikan Ipteks bagi Masyarakat yang dapat mendorong masyarakat desa Batursari untuk meningkatkan skill usahanya terutama dalam pemasaran hasil olah pertanian.

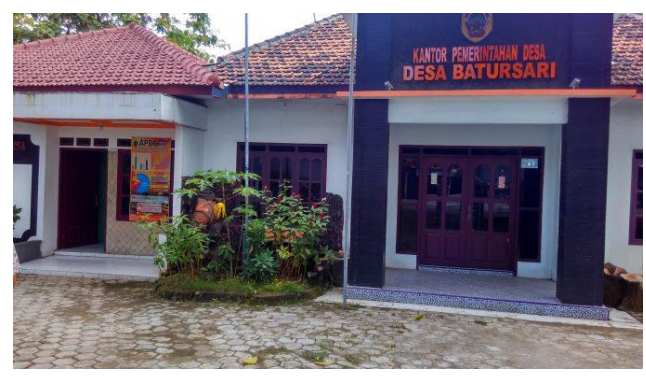

Gambar 1: Profil mitra 
Program Pemberdayaan Masyarakat dan UMKM ini dapat diaplikasikan sehingga pemanfaatannya sangat berguna bagi masyarakat sekitar. Kegiatan Ipteks bagi Masyarakat ini dilaksanakan di Balai Desa Batursari, Kecamatan Batangan Kabupaten Pati.

Berdasarkan permasalahan yang telah dijelaskan sebelumnya maka kegiatan ini mencoba memberikan pendampingan kewirausahaan olah hasil pertanian bagi masyarakat desa Batursari. Dalam menjalankan sebuah usaha, strategi pemasaran merupakan poin yang terpenting. Bisa dikatakan strategi pemasaran yang baik merupakan kunci keberhasilan penjualan produk. Oleh sebab itu, langkah-langkah dalam membuat strategi pemasaran sangatlah penting demi memaksimalkan kinerja usaha tersebut. Akan tetapi kualitas produk juga tetap perlu diperhatikan karena menjadi poin penting dalam pemasaran tersebut. Setelah memastikan produk memiliki kualitas yang baik, ciptakanlah strategi pemasaran yang baik dan efektif agar prosesnya dapat berjalan secara dinamis dan terkontrol. Semakin banyak pelaku usaha yang muncul maka persaingan pun akan semakin ketat, sehingga memaksa para pelaku usaha untuk menciptakan strategi pemasaran yang baru dan efektif dalam memenangkan persaingan yang ada.

\section{Metode Pelaksanaan}

Realisasi pemecahan masalah yang dilakukan dalam kegiatan ini adalah 1) perencanaan, 2) pelaksanaan, 3) follow up, 4) simulasi, dan 5) evaluasi. Untuk lebih jelasnya, dapat dilihat pada gambar berikut ini:

\begin{tabular}{|c|c|}
\hline \begin{tabular}{l}
\multicolumn{1}{c}{ Perencanaan } \\
Merencanakan kegiatan pendampingan \\
kewirausahaan olah hasil pertanian \\
masyarakat desa Batursari Kecamatan \\
Batangan Kabupaten Pati
\end{tabular} & $\begin{array}{l}\text { Pelaksanaan } \\
\text { masyarakat diberikan pengetahuan mengenai } \\
\text { strategi pemasaran dan keterampilan tentang } \\
\text { pembuatan media pemasaran yang efektif }\end{array}$ \\
\hline $\begin{array}{l}\text { Simulasi } \\
\text { Simulasi penggunaan media pemasaran } \\
\text { yang efektif }\end{array}$ & $\begin{array}{l}\text { Follow up } \\
\text { Masyarakat mampu praktik ujicoba membuat } \\
\text { sendiri media pemasaran hasil pelatihan }\end{array}$ \\
\hline \multicolumn{2}{|r|}{$\begin{array}{l}\text { encatat kendala, kekurangan, dan kelemahan } \\
\text { gunaan. Produk yang dihasilkan dalam } \\
\text { ektif }\end{array}$} \\
\hline
\end{tabular}

Gambar 2: Alur Realisasi

\section{Hasil dan Pembahasan}

Tim Program Pemberdayaan Masyarakat dan UMKM pengabdian masyarakat melakukan koordinasi dengan mitra untuk membahasa roadmap kegiatan antara lain: 
Jurnal SEMAR Vol. 9 No. 1 , hal. $1-6$

\section{a. Sosialisasi}

Sebelum melakukan kegiatan fisik di lapangan, maka kegiatan sosialisasi diadakan sebagai ajang saling mengenal antara tim pengabdian Universitas Muria Kudus dengan mitra. Termasuk dalam kegiatan sosialisasi adalah memfasilitasi warga untuk bermusyawarah dalam pendampingan kewirausahaan di Bumdes Prasaja kelompok bina farm.
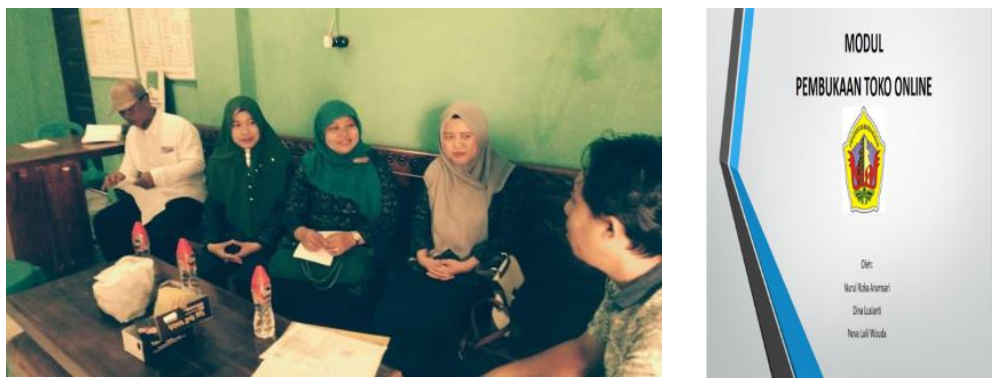

Gambar 3. Sosialisasi dengan mitra dan modul pelatihan

b. Penyusunan Materi

Modul pelatihan dibutuhkan agar pelatihan dapat berjalan lancar yaitu dengan membuat modul optimalisasi toko online untuk mengembangkan sistem pemasaran dan manajemen usaha serta meningkatkan keterampilan mitra.

c. Pelaksanaan pekerjaan di lapangan

Pelaksanaan pekerjaan di lapangan sekaligus merupakan ajang pelatihan bagi warga agar dapat mengelola dan membangun usaha secara mandiri. Dalam pelaksanaannya, mitra didampingi oleh pendamping yang terlatih. Misalnya untuk kegiatan motivasi kewirausahaan pendamping memberikan motivasi kepada mitra untuk melakukan penjualan secara elektronik agar produk yang sudah ada memiliki pangsa pasar yang lebih luas lagi dan dikenal banyak orang sehingga akan meningkatkan nilai produk tersebut. Selama ini penjualan elektronik tidak dikelola dengan baik oleh mitra dikarenakan kesibukan masing-masing pengelola. Pendamping mengingatkan kembali pentingnya komitmen dari masing-masing pengelola bumdes adalah untuk kemajuan bersama desa.
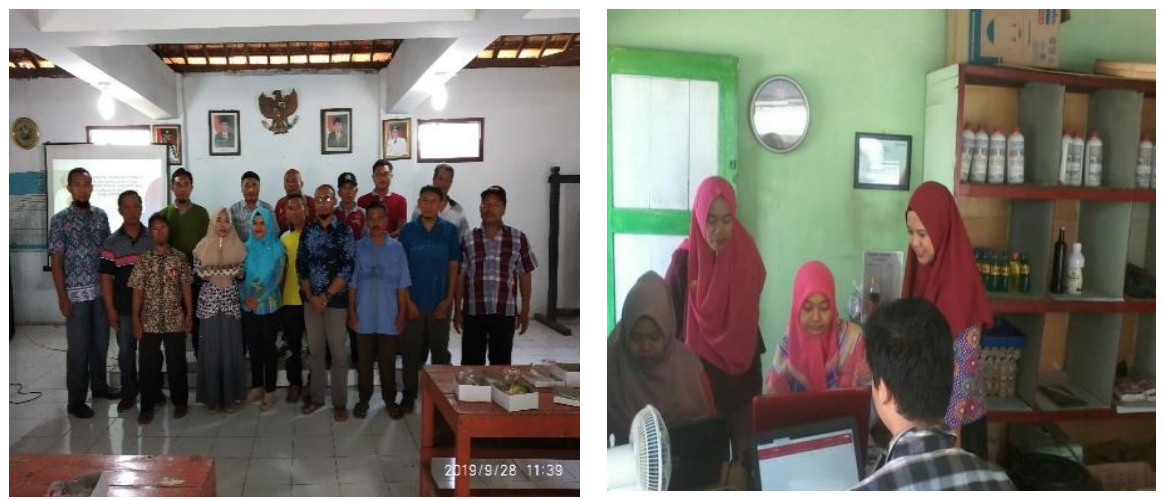

Gambar 4. Pendamping memberikan motivasi kepada mitra untuk melakukan penjualan elektronik (kiri). Pelatihan pembukaan toko online (kanan)

Tim juga memberikan pendampingan di bidang IT untuk menunjang mitra dalam menindaklanjuti pentingnya strategi pemasaran dengan memanfaatkan suatu teknologi yang dapat menunjang usaha secara mandiri. Tim memberikan pelatihan cara membuka toko online yang sedang diminati banyak khalayak. 
Selain itu mitra diedukasi mengenai re-packaging, yaitu menggunakan kemasan yang lebih menjual serta pemilihan kemasan yang ramah lingkungan dengan mengurangi penggunaan plastik adalah dengan memberikan solusi kemasan dari besek dimana besek ini terbuat dari anyaman bambu. Tim bekerjasama dengan pengrajin besek untuk memberikan alternatif kemasan sesuai dengan ukuran dan jumlah telur asap lurik yang akan dijual kepada konsumen.

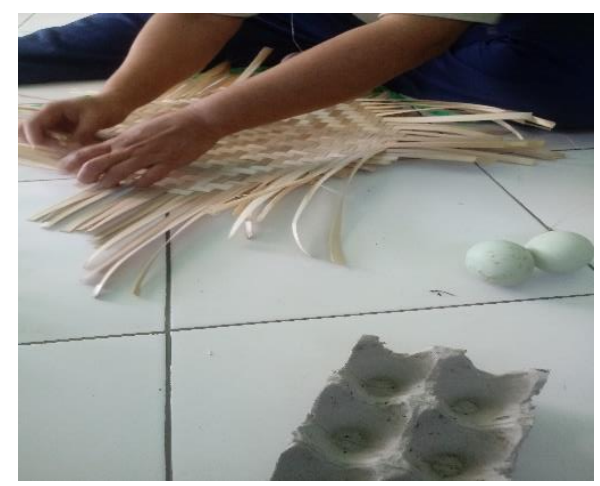

Gambar 5. Pembuatan kemasan dari besek

Perluasan pasar dapat terealisasi atas dukungan re-packaging yang baik yaitu dapat meningkatkan nilai suatu produk. Selain itu pangsa pasar menjadi luas setelah adanya sosialisasi dan pendampingan dalam pemasaran online yang memanfaatkan aplikasi toko online.

\section{Penutup}

Dari uraian pembahasan diatas permasalahan yang dihadapi mitra dan perlu untuk ditindaklanjuti adalah :

a. Komitmen dari para anggota Bumdes yang harus ditekankan lagi karena masing-masing anggota sibuk dengan kegiatan diluar bumdes yang cukup tinggi

b. Terbatasnya akses pasar karena jam operasional yang hanya mengandalkan 1 karyawan saja sehingga toko bumdes sering tutup jika karyawan tidak masuk sehingga peran toko online sangat diperlukan.

c. Keterbatasan jangkauan pemasaran mitra yang hanya sebatas sekitaran wilayah mitra saja.

d. Pemilihan kemasan yang ramah lingkungan dengan mengurangi kemasan dari plastik dapat sebagai alternatif pengganti.

Hasil pelaksanaan kegiatan pendampingan ini adalah sebagai berikut: 1) meningkatnya pemahaman mitra akan pentingnya komitmen dalam keberlanjutan usaha bersama; 2) meningkatnya ketrampilan di bidang teknologi informasi yaitu dapat mengoperasikan toko online; 3) meningkatnya pemahaman mengenai re-packaging yang lebih dapat menjual serta pemilihan kemasan yang ramah lingkungan dengan mengurangi penggunaan plastik. Kegiatan pendampingan sangat diperlukan agar mitra dapat mengelola usaha bersama secara berkelanjutan.

\section{UCAPAN TERIMA KASIH}

Ucapan Terima kasih dberikan kepada kepada :1) Universitas Muria Kudus yang telah mendanai kegiatan pengabdian masyarakat ini sehingga kegiatan dapat berjalan dengan lancar. 2) Pemerintah Desa Batursari Kecamatan Batangan Kabupaten Pati yang telah memberikan ijin atas terselenggaranya kegiatan pengabdian masyarakat ini serta 3) Seluruh pengelola Bumdes Prasaja atas kerjasamanya yang baik. 
Jurnal SEMAR Vol. 9 No. 1 , hal. $1-6$

ISSN: 2302-3937 | Copyright @ LPPM Universitas Sebelas Maret

Homepage: https://jurnal.uns.ac.id/jurnal-semar

\section{Referensi}

Arumsari NR dan Marka MM, 2018 Strategy Competitive Advantages through Marketing Performance, KINERJA Volume 22, No. 2, 2018 Page. 168-185

Kotler Philip \& Armstrong, Jakarta, 2008, Manajemen Pemasaran, Edisi Milenium, Jilid 3: Prenhallindo

Nawawi Hadari, 2008, Manajemen Sumber Daya Manusia Untuk Bisnis Yang Kompetitif, Yogyakarta : Gadjah Mada University Press

Swastha dkk, 2008, Manajemen Pemasaran Analisis Perilaku Konsumen, Yogyakarta : BPFE

Tjiptono Fandy, 2009, Strategi Pemasaran, Edisi 2, Cetakan ketujuh, Yogyakarta : Andi Offset

WP Sabar dan Parnanto, 2015. Peningkatan Usaha Telur Asin Asap. Jurnal Inovasi dan Kewirausahaan Vol.4 No.2

http://batursari-batangan.sideka.id/2017/07/27/inovasi-teknologi-dan-pengolahan- telur-asap-lurik-2/ diakses pada tanggal 16 Nopember 2018. 